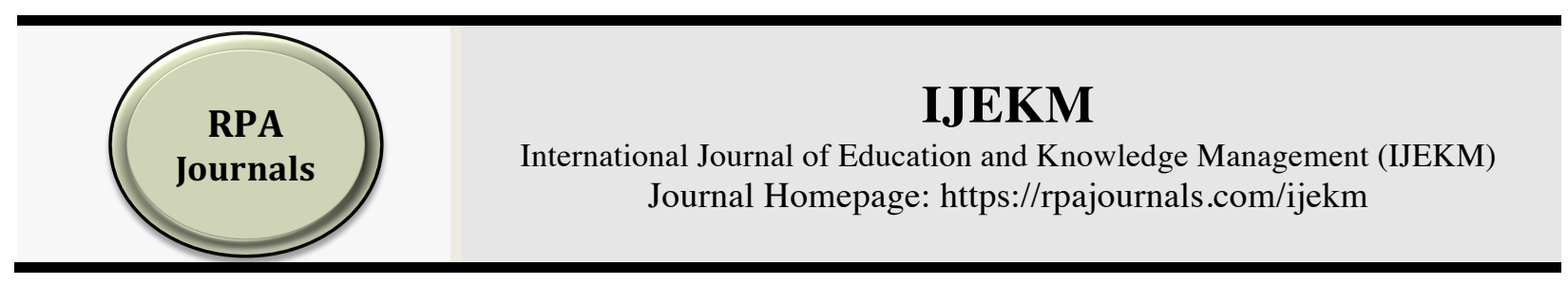

\title{
Muslim Patients Attitude an Alcohol Content in Cough Medicine: An Analysis in Islamic Perspective
}

\author{
Abdur Rakib Nayeem*1 \\ Issiagha Camara $^{2}$ \\ Thanhalul Alam Deep ${ }^{3}$ \\ Mohammad Abdul Zalil ${ }^{4}$ \\ Maryam Ladi Isa ${ }^{5}$ \\ Mst. Fatema Akter ${ }^{6}$ \\ Chongqing University (CQU), China ${ }^{1,2,3}$ \\ International Islamic University Malaysia (IIUM), Malaysia ${ }^{4}$ \\ Times University Bangladesh (TUB), Bangladesh ${ }^{1}$ \\ Federal University of Lafia, Nigeria ${ }^{5}$ \\ Southwest University (SWU), China ${ }^{6}$
}

\begin{abstract}
The Halalness of drugs an intriguing case to examine, given that the utilization of medications and halal food is a commitment for most of the Muslim populace. Since the legitimization of Law 33 of 2014 about Halal Product Assurance (UU JPH), there are still contrasts of supposition in a few services in Muslim Countries in regards to the execution of restorative items, particularly for prescriptions that are delegated life-sparing. This exploration means to examine the mentalities of hack victims towards the Halalness of hack medication and their demeanor towards medicine containing liquor. This investigation utilizes an observational plan, the exploration variable is the mentality towards halal and liquor content in drugs, furthermore, the medications got. The instrument utilized was a poll. The outcomes indicated that most of the patients needed halal medications and didn't contain liquor. From the information acquired, indicated that 68 percent of patients got cough medicine containing liquor between $2.50-10$ percent.
\end{abstract}

Keywords: Halal, Product, Medicine, Alcohol, Drugs, Cough.

*Corresponding author: Abdur Rakib Nayeem; Email: nayeem.phd@cqu.edu.cn DOI: https://doi.org/10.37227/IJEKM-2020-04-78

\section{Introduction}

The legality of medicine in Indonesia is a very interesting issue to discuss. This matter happened because the majority of Indonesian citizens were Muslim, while consuming halal and good food, drinks and medicines (not harmful) are mandatory for all Muslims, as the word of God in the Koran means as follows: "O people, eat halal again thayyiban from what is on earth, and do not follow the steps of Shaitan; because the real devil is the enemy real to you (Albaqarah verse 168). The verse shows that food that must be consumed by Muslims is not merely halal or thayyiban, but halal and thayyiban. Halal means that it is 
permissible under Islamic law, while thayyiban means good, clean, hygienic, and healthy. The opposite of halal is haram, which means it is not allowed based on Sharia Islam (Aziz 2012; Wahab 2004). "From Abu Darda ', he said: Rasulullah (Prophet Muhammad) said: Surely Allah has decreed disease and a cure for every disease, then repent and don't seek for the forbidden ones "(Hadith narrated by Abu Dawud). The hadith (the words of the Prophet Muhammad) show that if Muslims suffer illness it is forbidden use illicit drugs except in an emergency because no drugs have been found lawful. Since the enactment of Law 33 of 2014 concerning Halal Product Guarantee (Law JPH) on 17 October 2014, the government of the Republic of Indonesia is obliged to remind to all parties so that the Law is carried out properly without with the exception. Nevertheless, the facts explain that there are many trade-offs in several countries like Kora and Japan also (Nayeem, A.R. et al., 2020 ) and the ministries of the Republic of Indonesia related to the implementation of the JPH Law on drugs, especially for life-saving medicine. Rahman, A.H; (2020) shows in the research that Universities students are very conscious about Halal purchase intention specially young generations Muslim and non-Muslim consumer. There is an attempt to be excluded or excluded from liability halal medicine. Deputy Chairman of Commission VIII Iskan Qolba Lubis considered that both medicine and food are both required to be certified halal, including life-saving drugs. Taking halal medicine is an obligation for all Muslims when they are sick.

The reliability of the drug depends on the raw material of the drug, the production process and the storage of the product. Material the standard in question is all the ingredients contained in the drug, starting from the ingredients active, fillers and additives as a whole must come from halal ingredients. The production process also determines the halal nature of the drug, the halal material can be unclean if the process its production is in contact with material which is unclean or unclean. For example, in the manufacture of drugs $\mathrm{NaCl}$ infusion solution. In essence, $\mathrm{NaCl}$ is a salt that naturally includes food which is halal for consumption. However, during the production process filtration is usually carried out against $\mathrm{NaCl}$ so that the salt is whiter. The filter used is usually activated carbon derived from wood or bone. If by chance bones are used as activated carbon derived from pork bones, it means that the production process has come into contact with illicit goods, so that the productions are classified as illegal drugs. Storage of products is also a point critical halal medicine. For that storage must be kept away from unclean or unclean goods. Halal and good drugs must meet several criteria, namely; 1) does not contain material derived from animals is not halal or not slaughtered according to Islamic law, 2) no contains unclean ingredients according to Islam, 3) safe to use, non-toxic, and no endanger the health of its users, 4) is not produced using a tool contaminated with unclean, 5) does not contain human body parts or material that is prohibited according to Islamic law.

In addition to the above, alcohol is often used as a solvent in making drugs. Alcohol can have a negative impact on the wearer such as an impact on behavior that is lacking good so it is punished haram for Muslims. Gelatin commonly used as a shell capsules can also come from illicit goods such as pigs. For that we need guidance on how to manufacture Good halal medicine "Good Manufacturing Practices for Halal Pharmaceuticals" with steps as follows: Firstly, Must not contain ingredients derived from unclean animals or not slaughtered accordingly Islamic law. Secondly, Does not contain unclean ingredients such as ingredients from pork. Thirdly, Must be safe for human use; non-toxic, and not dangerous according to the dosage used. Fourthly, Prepared, processed,

International Journal of Education and Knowledge Management (IJEKM) 
and produced using equipment that is not contaminated with impurity. Fifthly, Does not contain ingredients derived from human body parts and Finally, During storage, production, maintenance, packaging, storage, and processes distribution must be separate from unclean and unclean products.

The JPH Law, issued in 2014, came into force on October 17, 2019. In reality, many people do not know about the implementation of the Act, including disease sufferers who consume drugs (Socialization of Halal Medicine, 1-31 August 2018). Besides it is still commonly found drugs, especially in the form of syrup preparations such as cough medicine. Some cough syrups contain alcohol which is not known by the user community. This study aims to analyze the attitudes and desires of cough sufferers towards halal drugs, and drugs that do not contain alcohol, as well as compliance with drugs that are obtained at Pharmacy. Based on the background above, the following problems can be formulated: Firstly, What is the attitude and desire of the cough sufferer towards the halal of drugs and drugs that are not contain alcohol? Secondly, Is the cough syrup obtained by the patient is halal certified and does not contain alcohol?

\section{Methodology}

In order to identify the attitude the patents, a qualitative method has been employed in this study. According to Somekh \& Lewin (2005), methodology of human behaviour is the interpretive paradigm, which recognizes subjectivity while implicitly adopting the perspective of the sociology of regulation. Based on face-to-face interviews with the reaction of the patients after taking the cough drags in Muslim Patients in Indonesia, the study offered a discussion of possible attitude of the medicine to cure themselves. Criteria for sample selection were that the respondents had after taking the alcohol added medicine in hospital and also in Islamic perspective. Selected respondent are cough sufferers or consumers who buy cough syrup medicine. Instrument used in this study is a questionnaire, so the requirements of respondents are: willing to be respondents, can read and write, and are Muslim. The variable in this study is the attitude of the respondents on the halal status of drugs, attitudes towards drugs containing alcohol, as well as the drugs obtained (whether the drug obtained is certified halal and does not contain alcohol). The participants were selected using non-probabilistic convenience sampling technique. The members of the sample were communicated directly and agreed with them for the interview on the appropriate date and time. After taking consent from the participants, the interviews were conducted with semi-structured questionnaires. It is then being written literally into transcriptions. This study uses observational design with sampling techniques using nonprobability sampling. This research was conducted on June-July, 2020 and limited for one month. The questions were clearly open-ended, giving the participants the freedom to express their opinion and to clarify their point of view comfortably (Islam, Hunt, Jantan, Hashim \& Chong, 2019). After that, Nvivo computer program (version 12) has been used to analyze the data (Bazeley \& Jackson, 2013).

\section{Results and Discussion}

\section{Characteristics of Respondents}

Respondent characteristics were analyzed according to the sex of the respondent. The respondents consisted of women are 76 percent and men are 24 percent as they are shown 
in Table 1.44 percent of respondents were clients and those who were work as pharmacists as much as 56 percent as shown in Table 2 .

Table 1. Gender of Respondents

\begin{tabular}{|c|c|c|c|}
\hline No & Gender & No. of respondents (people) & Percentage \% \\
\hline 1 & Male & 6 & 24 \\
\hline 2 & Female & 19 & 76 \\
\hline & Total & 25 & 100 \\
\hline
\end{tabular}

Table 2. The decision to choose a drug

\begin{tabular}{|c|c|c|c|}
\hline No & $\begin{array}{c}\text { The decision to choose drugs at the } \\
\text { Pharmacy }\end{array}$ & $\begin{array}{c}\text { No. of respondents } \\
\text { (people) }\end{array}$ & Percentage \% \\
\hline 1 & Clients & 11 & 44 \\
\hline 2 & Pharmacists / pharmacists & 14 & 56 \\
\hline & Total & 25 & 100 \\
\hline
\end{tabular}

\section{Attitude of Respondents towards Aspects of Objection}

Based on the attitude of respondents towards the halal aspect, as much as 100 percent of respondents agree to the halal status of medicinal products (Table 3). In addition, respondents also want it availability of halal drugs which are traded at pharmacies (Table 4). Halal food has criteria certain according to Islamic teachings which forbid eating pigs and the guidelines in animal slaughter. This rule is not only for daily food but also for medicines in pharmacy (Padela et al. 2011). Muslim communities are increasingly aware of the importance of halal in every aspect of life is one of them in health, namely the consumption of drugs. Islam governs it in full as outlined in the Koran, including in terms of food and medicine (Khattak et al. 2011). The drugs being traded are expected to have been certified so that they can be ascertained halalness. Islamic Sharia requires its adherents related to the consumption of drugs that medicine is not just effective for treating a patient's illness but also fulfills several aspects Halal, namely; raw materials, preparations, production processes, handling, processing, packaging or transportation of products, clean and free of non-halal materials, and only transportation used for halal products (Aziz et al. 2012). The increasing Muslim population is making demand for halal medicines as well increased (Norazmi 2015). On the other hand, the government is obliged to meet the needs of citizens Muslim to provide halal products.

The existence of the issuance of the JPH Law is in line with the wishes of the public regarding the halal products that are circulating, especially in the pharmaceutical world. The existence of the Act JPH will make it easier for people to choose halal products because the process of halal products is guaranteed by the state. Halal certification can reduce the possibility of producers to deceive consumers. Halal branding is not only noticed by people in Muslim countries, but has also been popular among non-Muslims as a symbol of healthy food (Salarvand and Pournia 2014). 
Table 3. Respondents' attitudes toward halal products

\begin{tabular}{|c|c|c|c|}
\hline No & $\begin{array}{c}\text { Attitudes of Respondents towards } \\
\text { halal medicine }\end{array}$ & $\begin{array}{c}\text { No. of respondents } \\
\text { (people) }\end{array}$ & Percentage \% \\
\hline 1 & Agree & 25 & 100 \\
\hline 2 & Disagree & 0 & 0 \\
\hline & Total & 25 & 100 \\
\hline
\end{tabular}

Table 4. Respondents' desires for halal drugs

\begin{tabular}{|c|c|c|c|}
\hline No. & $\begin{array}{c}\text { Desire of respondents towards } \\
\text { halal medicine }\end{array}$ & $\begin{array}{c}\text { No. of respondents } \\
\text { (people) }\end{array}$ & Percentage \% \\
\hline 1 & Want & 25 & 100 \\
\hline 2 & Don't Want & 0 & 0 \\
\hline & Total & 25 & 100 \\
\hline
\end{tabular}

There is a correlation between food, culture, and religion (Wilson and Liu 2011). Desire to buy halal products is influenced by aspects of religion and social norms. besides too influenced by friends, family, or groups that encourage someone (Mukhtar and Mohsin 2012). Some consumers describe that halal food is better for health and also in terms of other qualities (Padela et al. 2011). Even non-Muslims also believe in products that has a halal logo, because the product is definitely not only clean and delicious, but also processed in the best way (Garg and Joshi 2018) Like for example the procedure for slaughtering animals which is done in a good way.

Today, Muslim consumers are more sensitive and aware of the halal status of their products bought. They tend to choose products that are in accordance with the principles of Islamic law, namely with looking for halal products. To be able to find out the halal product one of them can be seen the existence of a halal logo on the packaging. Halal logo now is not only for food, but also has been widely used for cosmetics, pharmaceuticals, and so on. This happens because there is several product discoveries that use pork as a basis for gelatin as well illicit alcohol use (Garg and Joshi, 2018). Products that have included a logo Halal means that it has passed the certification. Based on observations, if consumers do not find the halal logo on the packaging, they will move on to look for other products that can already be confirmed halal status (Afendi et al. 2014).

Halal logo on the packaging provides important information to consumers. Through the logo These, consumers do not need to bother to check the composition one by one on product. But when no halal logo is found, then the consumer will be in doubt. There are two possibly, the first is because the product contains ingredients that are not halal or the second possibility is that producers have not yet registered their products for halal certification.

In Islam, a Muslim is expected to stay away from any food or medicine that comes from dubious sources (Aziz et al. 2012). Manufacturers adjust to the needs and desires of consumers when taking production decisions for a product. Meanwhile, consumers in determining attitudes and the behavior of the goods and services purchased is heavily influenced by religious aspects.

Religion is a belief that influences one's decisions and satisfaction (Mukhtar and Mohsin Butt 2012). A Muslim who adheres to Islamic law will think first and make religious rules as a reference for making decisions in buying goods (Nature et al. 2011). When there are two things that are the same, a Muslim will be more prioritizing buying 
goods that have been halal certified (Azmi et al. 2010). Most of the production of goods is influenced by aspects of religiosity to fulfill consumer needs (Rehman and Shabbir, 2010). Important for producers or suppliers of goods and services to understand that religion or sharia is also a factor in buying goods that are appropriate and permissible in religion (Weaver and Agle 2002). Religion directs life and influence individual decisions. Not only shapes behavior but also set the value and take the attitude and consideration in buying goods (Shyan Fam et al. 2004). Consumers tend to avoid dubious products (subhat) and prefer ones lawful to avoid consuming products that are prohibited in religious provisions. When manufacturers can provide halal products, it will encourage customers to choose and buy more products that are halal certified (Garg and Joshi 2018). There must be a uniform guideline that must be met by every halal producer. Including help consumers to get a source of halal products on the open market. That company all procedures will be given halal certificate. In addition, the halal logo must be printed with clearly on product packaging to make it easier for consumers to choose halal products (Aziz et al. 2012)

\section{Respondents' attitudes toward non-alcoholic drugs}

Based on the results of research on the attitudes and desires of respondents towards drugs that does not contain alcohol known that as many as 100 percent of respondents agreed that the drug should not contain alcohol (Table 4) and want drugs to be traded no alcohol composition (Table 5).

Table 5. Respondents' attitudes toward non-alcoholic drugs

\begin{tabular}{|c|c|c|c|}
\hline No & $\begin{array}{c}\text { Attitudes of Respondents towards drugs which } \\
\text { does not contain alcohol }\end{array}$ & $\begin{array}{c}\text { No. of respondents } \\
\text { (person) }\end{array}$ & Percentage \% \\
\hline 1 & Agree & 25 & 100 \\
\hline 2 & Disagree & 0 & 0 \\
\hline & Total & 25 & 100 \\
\hline
\end{tabular}

Table 6. Respondents' desires for non-alcoholic drugs

\begin{tabular}{|c|c|c|c|}
\hline No & $\begin{array}{c}\text { Desire of respondents towards drugs } \\
\text { which does not contain alcohol }\end{array}$ & $\begin{array}{c}\text { No. of respondents } \\
\text { (person) }\end{array}$ & Percentage \% \\
\hline 1 & Want & 25 & 100 \\
\hline 2 & Don't Want & 0 & 0 \\
\hline & Total & 25 & 100 \\
\hline
\end{tabular}

The chemical and pharmaceutical industries use alcohol a lot, especially in the process production and reaction. Alcohol is widely used as a solvent because there are several ingredients which cannot be dissolved with plain water so alcohol solvents are needed. Such as to dissolve fats and some organic compounds (Mursyidi 2002). Chemically, alcohol is a term for any organic compound that has a group hydroxyl $(-\mathrm{OH})$ which is bound to carbon atoms such as methanol, ethanol, propanol, butanol, pentanol and others (Park et al., 2016). Ethanol is a type of alcohol that is commonly consumed as liquor including illicit drinks (Jahangir 2016). Food and drug production processes usually use ethanol $(\mathrm{C} 2 \mathrm{H} 5 \mathrm{OH})$. Ethanol is often referred to as a trade name alcohol. If observed from the production process, alcohol can originate from the khamr industry indeed produce alcohol as a liquor and some are derived from the results of chemical synthesis or nonkhamr fermentation industry. There are various opinions about the halal status of alcohol. Some argued that the alcohol contained in a product regardless of the level, then still condemned haram. There are also requirements for alcohol content in the product, for 
example according to position Malaysian Islamic Progress (JAKIM) which limits the halal of the product if it contains alcohol a maximum of 0.5 percent and the Research Association for the Inspection and Certification of Food and Supplies (GIMDES) in Turkey which limits the halal of a product if it contains alcohol maximum of 0.3 percent (Lukmanudin 2015). Whereas based on the fatwa of the Indonesian Ulema Council (MUI), the use of alcohol from The results of the khamr industry for food products, beverages, cosmetics, and medicines are haraam. If alcohol comes from chemical synthesis results the law changes if it is medically harmless (Najiha et al. 2010). But the law can be haram if medically harmful (MUI Fatwa number 11 of 2009 concerning alcohol; Najiha et al. 2010).

Table 7. Cough medicine obtained by respondents at pharmacies

\begin{tabular}{|c|c|c|c|c|}
\hline No & Medicine name & $\begin{array}{c}\text { Content } \\
\text { Alcohol (\%) }\end{array}$ & $\begin{array}{c}\text { No. of } \\
\text { Respondents } \\
\text { (Person) }\end{array}$ & Percentage \% \\
\hline 1 & Actifed plus expectorant & 2.50 & 5 & 20 \\
\hline 2 & Actifed plus cough suppressant & 9.90 & 3 & 12 \\
\hline 3 & Vicks formula 44 & 10 & 1 & 4 \\
\hline 4 & Bisolvon elixir & 3.72 & 3 & 12 \\
\hline 5 & Woods & 6 & 5 & 20 \\
\hline 6 & Triaminic & 0 & 3 & 12 \\
\hline 7 & OBH Nelco Spesial & 0 & 3 & 4 \\
\hline 8 & Lapifed ekspektoran & 0 & 1 & 4 \\
\hline 9 & Siladex & & 1 & 100 \\
\hline
\end{tabular}

But in fact, of the nine kinds of cough medicine at the pharmacy, there were 68 percent alcoholic products. The composition of alcohol in the drug ranges between 2.5 percent up to 10 percent (Table 7). Cough medicines that contain alcohol include Actifed plus expectorant of 2.5 percent, Actifed plus cough suppressant of 9.9 percent, Vicks formula 44 by 10 percent, Bisolvon elixir by 3.72 percent, and Woods by 6 percent. While in Triaminic, OBH Nelco Special, Lapifed Expectorant, and Siladex there were no compositions alcohol on drug packaging. Although there is no alcohol composition, it is also not found Halal logo on the packaging. The absence of alcohol composition may not cough medicine add alcohol to the liquid medicine, or indeed the manufacturer does not include alcohol as an additive to the drug.

A drug contains two categories of ingredients namely active and inactive (excipients). The active ingredient is the main substance used to treat disease. Usually only there is one kind of active ingredient in a drug. While the excipient material can be more than five kinds of substances. These excipients are added to the drug to improve the quality of the drug such as flavors, coloring, forming tablets, solvents, and other benefits that can improve the quality of the drug (Aziz et al. 2012). Of the 25 respondents, 68 percent of respondents bought cough medicines containing alcohol while the remaining 32 percent get cough medicine without alcohol. Alcohol has several functions in the preparation of medicines. First as a preservative, content alcohol more than 18 percent can only be used as a preservative (preservative). Second as a solvent for active substances and additives in tablet preparations, increasing drug solubility (kosolven) with the main solvent of water in the oral solution preparation, but also as a solvent solution injection. Third, as a flavor (freshener) with alcohol content usually between 1 - 5 percent (Mursyidi 2002). The use of 
materials that are categorized as haram in Islam is still often used in the manufacture of medicines in the pharmaceutical world because there are no alternative substitutes. Unlawful material, may be used as long as in emergency conditions (urgent or emergency). For example capsule shells derived from pig gelatin and insulin derived from pigs for diabetics. The use of drugs with a mixture of illicit ingredients is permitted because Darurah reasons until finally found alternative halal materials (Isa 2016).

A Muslim must consume food that is clean, pure, hygienic, and of good quality also known as halalan thayyiban. Muslims believe that choosing daily food which is halal and choose halal medicine to cure diseases including in matters of worship. A narrow understanding of halal is free from non-halal or non-halal materials contain pork and alcohol. while the real concept is to ensure that throughout the product preparation process meets the requirements. During preparation, handling, processing, packaging or transporting the product, the product must be clean and free of non-halal materials and transportation is only used for halal products (Aziz et al. 2012). Related to the above, the state guarantees the independence of every resident to embrace their respective religions and to worship according to their religion and beliefs. Thing This is as mandated in the 1945 Constitution of the Republic of Indonesia Article 29 paragraph 2. Therefore, the state is obliged to provide protection and guarantees halal products for the Muslim community given that the majority of Indonesia's population is Muslim. This guarantee aims to provide comfort, security, and safety halal product certainty (Syafrida 2015). Cooperation between governments, pharmaceutical companies, scholars Islam, and health care professionals are suggestions for achieving goals towards halal treatment (Aziz et al. 2012).

\section{Research Limitation and Suggestion for Future Research}

Right off the bat, a portion of the respondents, particularly those at the administrative level, were commonly occupied and reluctant to give certain data about their establishments. Be that as it may, the scientists put forth a few attempts through visits and correspondence on calls to get sufficient respondents. Furthermore, specialists of organizations were hesitant to unveil and not enough data about the disposition of the patients who needs to consume the medications to fix from the hack. In any case, the specialists consoled them that the data acquired from them would be utilized uniquely for the investigation. Thirdly, the investigation was constrained by the utilization of organized polls as apparatuses for information assortment. The instruments were shut finished and denied the respondents the opportunity to communicate their assessments outside the structure. Further exploration should concentrate on the effect and fulfilment of utilizing the hack medication for the Muslim patients in Indonesia.

\section{Conclusion}

All Muslim patients as respondents of this study with (100 percent) agreed with the halal status of medicinal products and wanted the availability of halal drugs which are traded at pharmacies in the country anywhere. In addition, they are also agreed and wanted the medicine obtained from the pharmacy not to contain alcohol composition, especially from Muslim countries like Indonesia, Malaysia, Nigeria and so on. As many as 68 percent of respondents buy cough medicines that contain alcohol grading 2.5 to 10 percent. Cough medicines that contain alcohol include Activated plus expectorant, Active plus cough suppressant, Vicks formula 44, Bisolvon elixir and Woods. While in Triaminic, OBH Nelco Special, Lapifed Expectorant, and Siladex there were no compositions alcohol.

International Journal of Education and Knowledge Management (IJEKM) 


\section{References}

Afendi, N. A., Azizan, F. L. and Darami, A. I. (2014). Determinants of Halal

Purchase Intention: Case in Perlis. International Journal of Business and Social Research. 4(5): 118-125.

Alam, SS., Mohd, R., dan Hisham, B. (2011). Is Religiosity an Important Determination on Muslim Consumer Behaviour in Malaysia? Journal of Islamic Marketing. 2(1): 83-96

Aziz, N. A., Majdina, H ., Hassan, Y., Zulkifly, H. H., Wahab, M. S. A., Aziz, M. S.

A., Yahaya, N., AbdulRazzaq, HA. (2012). Assessment of the Halal Status of Respiratory Pharmaceutical Products in a Hospital. 121: 158-165.

Azmi, A. A., Muslim, A. and Zaidi, I. (2010). The Perception to Choose Halal Cosmetics Products: An Empirical Study for Malaysian Consumer. Paper Presented at 6th International Conference on Business. Management and Economics. Turkey: Yasar University.

Garg, P. and Joshi, R. (2018). Purchase Intention of "Halal" Brands in India: The Mediating Effect of Attitude. Journal of Islamic Marketing. 9(3): 683-694.

Isa, N. M. 2016. Darurah (Necessity) and Its Application in Islamic Ethical Assessment of Medical Applications: A Review on Malaysian Fatwa. Sci Eng Ethics 22: 1319-1332.

Jahangir, M., Mehmood, Z., Saifullah, Z., Bashir, Q., Mehboob, F., and Ali, K. (2016). Halal Status of Ingredients after Physicochemical Alteration (Istihalah). Trends in Food Science \& Technology. 47: 78-81.

Khattak, J. Z. K., Mir, A., Anwar, Z., Wahedi, H. M., Abbas, G., Khattak, H. Z. K. (2011). Concept of Halal Food and Biotechnology. Advance Journal of Food Science \& Technology. 3(5).

Lukmanudin, M. I. (2015). Legitimasi Hadis Pelarangan Penggunaan Alkohol dalam Pengobatan. Journal of Qur'an and Hadith Studies. 4(1): 79-101.

MUI (Majelis Ulama Indonesia). (2010). Fatwa Majelis Ulama Indonesia No. 11

Tahun (2009) tentang Hukum Alkohol. Diakses Mei pada http://www.halalmui.org/images/stories/Fatwa/fatwaalkohol.pdf

Mukhtar, A. and Mohsin Butt, M. (2012). Intention to Choose Halal Products: The Role of Religiosity. Journal of Islamic Marketing. 3(2): 108-120.

Mursyidi, A. (2002). Alkohol dalam Obat dan Kosmetik. Tarjih. 4: 26-36.

Nayeem, A. R. et al. (2020). Halal Food Concept and Impact on Tourism Industry in Japan and South Korea, East African Scholars J Econ Bus Manag; 3(6): 515-521.

Najiha, A. et. al. (2010). A Preliminary Study on Halal Limits for Ethanol Content in Food Products. Middle-East Journal of Scientific Research. 6(1): 45-50.

Norazmi, M. N., Lim, L. S. (2015). Halal Pharmaceutical Industry: Opportunities and Challenges. Trends in Pharmacological Sciences. 36(8): 496-497.

Padela, A. I., Gunter, K., Killawi, A., Heisler, M. (2011). Religious Values and Healthcare Accommodations: Voices from the American Muslim Community. $J$ Gen Intern Med. 27(6): 708-715.

Park, S., Kim J. C., Lee, H. S., dan Jeong, S. W. (2016). Determination of Five Alcohol Compounds in Fermented Korean Foods Via Simple Liquid Extraction with Dimethyl-sulfoxide Followed by Gas Chromatography-mass Spectrometry for Halal Food Certification. Food Science and Technology. 74: 563-570 
Rahman, A. H. et.al. (2020). Purchase intention of halal food among the young university students in Malaysia. Globus An International Journal of Management \& IT. 12(1): 6-13.

Rehman, A. and Shabbir, S. M. (2010). The Relationship Between Religiosity and New Product Adoption. Journal of Islamic Marketing, 1(1): 63-69.

Salarvand, A. and Pournia, Y. (2014). Perception of Medical University Members from Nutritional Health in the Quran. Iran Red Crescent Med J. 16(4): 1-8.

Syafrida. (2015). Sertifikat Halal pada Produk Makanan dan Minuman Memberi Perlindungan dan Kepastian Hukum Hak-Hak Konsumen Muslim. ADIL: Jurnal Hukum. 7(2): 159-174.

Wahab, AR. (2004). Guidelines for the Preparation of Halal Food and Goods for the Muslim Consumers. AmalMerge Halal and Food Safety Institute.

Weaver, G. R. and Agle, BR. (2002). Religiosity and Ethical Behavior in Organizations: a Symbolic Interactionist Perspective. Academy of Management Review. 27(1): 77-97.

Wilson, J. A. J., Liu, J. (2011). The Challenges of Islamic Branding Navigating Emotions and Halal. Journal of Islamic Marketing. 2(1): 28-42. 